\title{
The Impact of Storytelling on the Intentions of Egyptian Restaurant Customers
}

\section{Mohammed Zohry}

Associate Professor, Department of

Hotel Studies

Shaimaa Ali Fawzy

Associate lecture, Department of Hotel Studies

\section{BY}

\author{
Ahmed Saleh Saleh
}

Associate lecture, Department of Hotel Studies

\section{Mohammed Alaa Ibrahim}

Demonstrator, Department of Hotel Studies

Faculty of Tourism and Hotels - Mansoura University

\section{Doi: 10.21608/kjao.2021.193075}

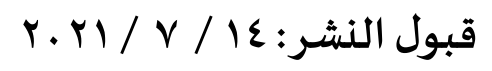

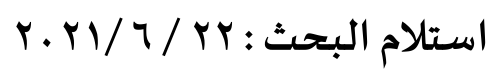

Zohry,Mohammed Abd \& Saleh, Ahmed Saleh \& Fawzy, Shaimaa Ali \& Ibrahim , Mohammed Alaa (2021). The Impact of Storytelling on the Intentions of Egyptian Restaurant Customers, The Arab Journal of Tourism, Hospitality and Archeology Sciences, AIESA, vol (2), N (3), pp 159- 194. 


\section{The Impact of Storytelling on the Intentions of Egyptian Restaurant Customers}

\section{Abstract}

This research aims to examine the impact of storytelling on the intentions of Egyptian restaurant customers and examine how customers perceive storytelling at the restaurant. Restaurants use storytelling to emotionally connect with customers, highlight their strengths, preserve their great image, and reinforce their strengths while minimizing their weaknesses. For achieving the research aim, an electronic questionnaire was designed and distributed to a random sample of customers in Egyptian restaurants. Participants received information to examine the effects of storytelling and to evaluate their purchasing intentions towards restaurant stories using a five-point Likert scale, which 396 responses were received and valid to analyze by SPSS V.25. Results indicated that investigated customers have sufficient awareness of restaurant storytelling. With regard to analyze customers' intentions towards storytelling, the majority of customers are aware of storytelling concept and intend to go to a restaurant that uses this perspective, which the average of respondents' answers was agree in some statements. Based on the results, some recommendations have been proposed, "Training employees on how to use the marketing storytelling perspective" and also It is recommended that the restaurant management be hired in officials or marketing personnel who have sufficient experience with the concept of storytelling.

Key Words: Storytelling, Consumer Perception, and Behavior, Consumption Value, Purchasing Intention, Egyptian Restaurant.

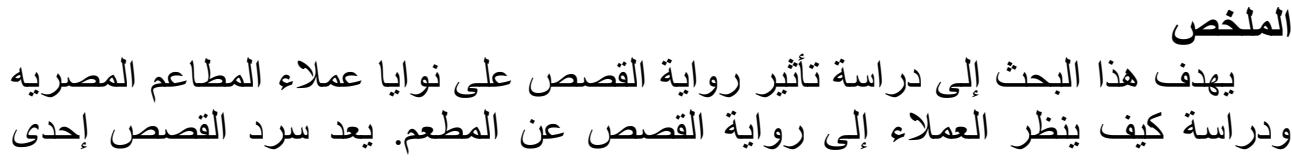

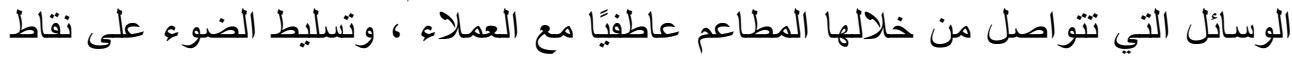

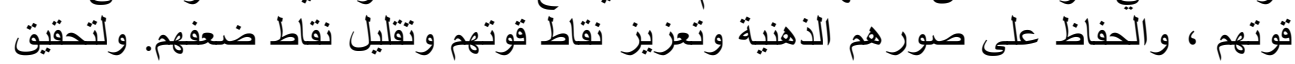

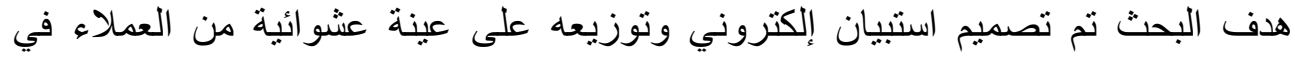




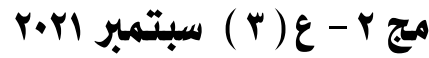

\section{المجلة العربية لعلومر السياحة والضيافة والآثار}

المطاعم المصرية، تلقى المشاركون بعض المعلومات لمعرفة وفحص نأثيرات سرد

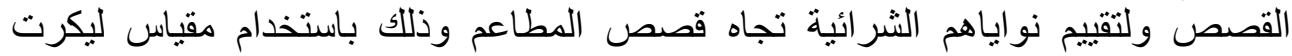

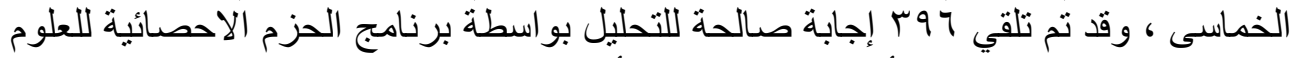

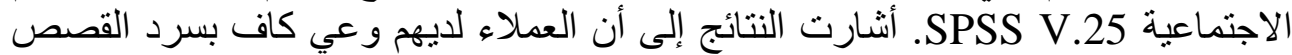

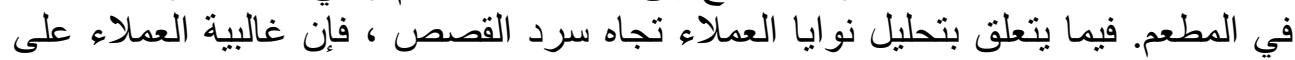

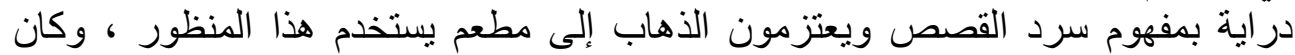

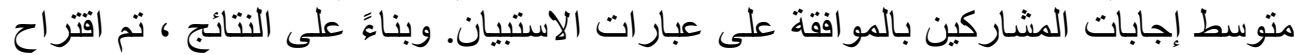

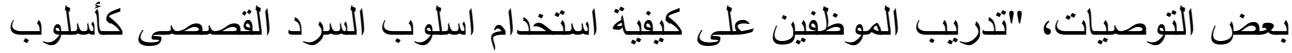
تسويقى وتعبين إدارة المطعم للعاملين الذين لديهم الخبرة الكافية والقدره على التى الاقناع من

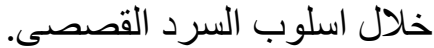
الكلمات المفتاحية: السرد القصصى الصىى، تصور وسلوك المستهلك، قيمة الاستهلاك، نوايا

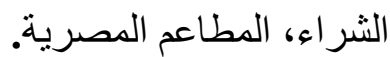

\section{Introduction}

Customer connections are often fostered through the use of stories in restaurants (Healey, 2008). Customers are drawn to a good narrative, which helps restaurants develop their identity, values, and reputation among competitors (Hermansson \& Na, 2008). For millennia, humans have been telling stories to one another. Food, which is steeped in long-standing cultures and customs, may serve as a rich source of storytelling material for differentiating meals and adding value (Park \& Cho, 2010). In addition, value is a key component in customer decision making, purchase intention, and a vital marketing process (Kotler and Kevin, 2006). Storytelling, according to Simmons (2006), is an emotional connection and a marketing strategy focused on the design, development, and dissemination of compelling tales that have a direct or indirect link to companies.

\section{Research's Problem}

The research's problem is that necessary to pay attention to new techniques in marketing such as storytelling. Storytelling is method that has been actively studied in the hospitality industry as well as the restaurant industry. Storytelling is a powerful influence because 
products or services containing stories that appeal to consumers' emotions or dreams and move their minds may have higher value than functional values centered on price or quantity (Van Hulst, 2012).

\section{Research's Aim}

Accordingly, the research aims to examine the impact of storytelling on the intentions of Egyptian restaurant customers and determine whether there is a difference in the intentions of customers back to their demographic data and their object data.

\section{Research's Significance}

The significance of this study was to show how customers perceive storytelling at a restaurant. As a result, this study examined the potential power of storytelling as an effective marketing communication tool for restaurants.

\section{Research Limitations}

Limitations of the study are divided into three limitations. Place limitations represented in Cairo Greater and Mansoura as a representative sample of the Egyptian restaurant's society. Human limitations represented in customers of the investigated restaurants as a sample of the study. Time limitations represented in addressing questionnaire forms to the investigated customers in the period from $20^{\text {th }}$ October, 2020 to $25^{\text {th }}$ December, 2020.

\section{Research Hypothesis}

Based on the reading about the subject of storytelling, the research hypothesis suggested as follows:

- There are significant differences between the impact of storytelling on the intentions of Egyptian restaurant customers according to their demographical data ("H 1.1" gender, "H 1.2" age, "H 1.3" marriage status, "H 1.4" educational level, and $\mathrm{H}$ 1.5" monthly income).

- There are significant differences between the impact of storytelling on the intentions of Egyptian restaurant customers according to their object data ("H 2.1" How often you eat out?, "H 
2.2" How willing to visit a restaurant just for hearing a story?, "H 2.3" Have you visited a restaurant that uses storytelling as a marketing tool?, "H 2.4" Did you tell a story about a restaurant based on a previous experience of visiting it?, "H 2.5" What attraction does the restaurant use as a storytelling marketing tool?, " $\mathrm{H}$ 2.6" What factors help you in making the decision to go to restaurants?). 
I

H 1.1

$\mathrm{H} 1.4$

Gender
H 1.2

$\mathrm{H} 1.5$

H 1.3

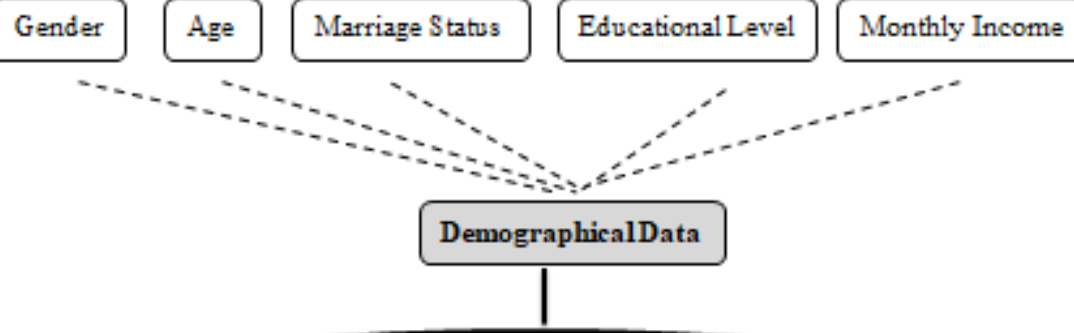

The Impact of Storytelling on the Intentions

of Egyptian Restaurant Customers

$\mathrm{H}$

H 2.2

Times Eating Out

$\mathrm{H}$

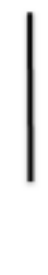

H 2.4

Figure 1: Research Hypothis

2.1

Visiting a Restaurant Using Storytelling as a Marketing Tool

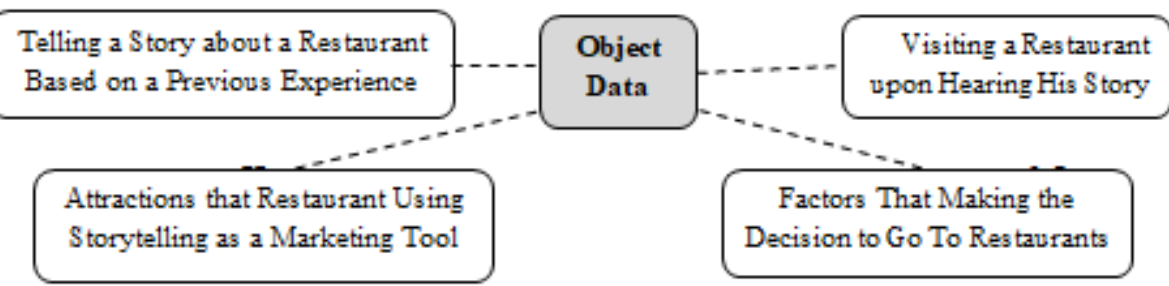




\begin{tabular}{|c|c|c|c|}
\hline \multicolumn{4}{|c|}{ Source: ResearchersResearch Gap Analysis } \\
\hline Research Gap & Research's Aim & Sample / Population & $\begin{array}{l}\text { Results/ } \\
\text { Recommendations }\end{array}$ \\
\hline $\begin{array}{l}\text { 1- Brand } \\
\text { Storytelling: A } \\
\text { Comparison of } \\
\text { The Brand } \\
\text { Stories of } \\
\text { Tiffany and } \\
\text { Bulgari } \\
\text { By: (He, 2011) }\end{array}$ & $\begin{array}{l}\text { The study } \\
\text { discusses reasons } \\
\text { that explain the } \\
\text { similarities and } \\
\text { differences and } \\
\text { how those brands } \\
\text { use stories as one } \\
\text { of the branding } \\
\text { components of } \\
\text { success }\end{array}$ & $\begin{array}{l}\text { Tiffany \& Co. and Bulgari. } \\
\text { Tiffany \& Co. } \\
\text { Tiffany \& Co., founded in } \\
\text { 1837, has promoted itself as } \\
\text { the world's premier in the } \\
\text { field Bulgari started its } \\
\text { business in the late 19th } \\
\text { century, and since then. } \\
\text { Those brands have been } \\
\text { widely known for a long } \\
\text { time. Their names, logos, and } \\
\text { symbols represent quality } \\
\text { and a certain lifestyle and } \\
\text { value in people's minds. }\end{array}$ & $\begin{array}{l}\text { - It was determined } \\
\text { that there are both } \\
\text { parallels in brand narrative } \\
\text { and variances between the } \\
\text { two brands after } \\
\text { examining } 79 \text { Tiffany } \\
\text { releases and } 40 \text { Bulgari } \\
\text { releases in the research. } \\
\text { Prior to, through, and after } \\
\text { the recession, the two } \\
\text { brands' storylines } \\
\text { diverged, according to the } \\
\text { findings. } \\
\text { - The investigation } \\
\text { was able to understand the } \\
\text { tactics that allowed } \\
\text { Tiffany's to outperform } \\
\text { Bulgari. Both possibilities } \\
\text { and problems abound in } \\
\text { today's premium market. } \\
\text { In recent years, consumers } \\
\text { have grown more } \\
\text { educated, sophisticated in } \\
\text { terms of taste and price } \\
\text { comparison tactics, and } \\
\text { more interested in value } \\
\text { and status than they were } \\
\text { in the past. A firm must } \\
\text { discover a way to attract } \\
\text { the attention of customers. }\end{array}$ \\
\hline
\end{tabular}




\section{2- The Effect of \\ Storytelling on Purchase \\ Behavior in \\ Local Food \\ Restaurant}

By: (Park \&

Cho, 2010)
The aim of this study was to examine how customers perceive storytelling at a real local restaurant and to understand how consumption reflects their evaluation by understanding their values.
1- Participants received information from a real local restaurant in the Gangneung area to examine the effects of storytelling and to evaluate their affective attitudes towards local restaurant stories, word-of-mouth intentions, and purchasing intentions using a sevenpoint Likert scale. A total of 310 consumers were used.

2- A factor analysis was performed to identify consumption value characteristics and factor structure, which consisted economic value, emotional value, and epistemic value.

To test whether local restaurant consumers could be classified into homogenous groups based on their consumption values, a three-cluster solution was selected, and a K means cluster analysis was performed.
- Using the scores for each of the consumption values, three groups were discovered and labelled: emotional value-oriented customers were placed in cluster 1 , epistemic valueoriented consumers were placed in cluster 2 , and economic value-oriented consumers were placed in cluster 3. Comparing affective attitudes toward storytelling at local restaurants, purchase intentions, and word-ofmouth intents across the three clusters was done using an analysis of variance.

- To understand how consumers, evaluate a restaurant's ability to tell stories by examining their consumption values, this study was important. This research evaluated the potential of storytelling as a marketing communication strategy for local eateries.

The restaurant selected for this case study was a Midwestern customer-service based organization composed of approximately 580 employees. This not-forprofit cooperative is nearly 90 years old and is widely known for putting people before profits; it has a strong culture supporting community service and participants' remarks were summarized and recorded throughout the discussion, and then combined into one document following the dialogue. Researchers used text analysis to uncover themes relating to employee behavior and fundamental beliefs. As a result of this research, four
- Discussion core values, improve organizational 
performance, and achieve its mission. significant philanthropic activities. The organization in this ALIGNING EMPLOYEE BEHAVIOR WITH CORE VALUES 23 study reported higher-thanindustry-standard customer satisfaction scores in 2018. It has over 200,000 customers and is highly competitive in its market, recently named best-in-state main themes emerged: 1 ) The core value of "caring" is expressed in words or stories that provide behavioral clarity, 2) Excellence and Integrity require greater behavioral definition and clarity, 3) Participants perceive a values-based difference between this organization and others, and 4) Participants recognize the need and/or opportunity to become better.

- Through storytelling, participants gave recommendations for improvements that management might implement and sustain at all levels. A greater alignment of employee behavior with core values and improved organizational performance may result from implementing these enhancements. Other customer-service businesses may use this study's organization development theory and concepts, including inquiry and storytelling, to enable positive change while increasing their competitive advantage in the market.

Previous studies dealt with different ideas about the impact of storytelling on brand sales, as well as about customers' perceptions of 
storytelling and its impact on consumption, then strategies that affect the behavior of employees and improve their organizational performance to implement storytelling well, while the current studies are based on studying the relationship between storytelling and customer intentions.

\section{Literature Review:}

\section{Storytelling as A Marketing Communication Tool in Restaurant}

A story has a structure that keeps it together and engages the listener. Brand stories resemble traditional fairy stories (Twitchell, 2004), which answer questions such as: who, what, why, where, when, how, and with the help of what (Shankar et al, 2001). Stories always make a point that is valued (positively or negatively) by the audience (Fog et $a l, 2010$ ). Each story should convey only one single message, which has clearly focused so that it can be summarized in only one or two sentences (Twitchell, 2004). While the notion of a restaurant brand narrative isn't new, many marketers haven't completely grasped it (Hamm, 2013). Storytelling is an organization's best-hidden weapon in its drive to separate itself from its rivals, as All (2013) points out: "Great stories are more important than ever to a brand than ever before." Readers who are interested in learning more about restaurant brand narrative ideas may do it elsewhere (Fog et al., 2010).

Restaurant marketing is no longer a one-way exchange due to the development of information technology and the growth of new marketing challenges. Instead, bloggers or members can now respond or give feedbacks, making storytelling a more widely used tool for two-way communication between a brand and its target customer groups (Solja, 2017). As Healey (2008) pointed out, the narrative is one of the most important components of brand identity and positioning. Company employees may use storytelling to ensure they are working toward the same goals, and potential consumers can hear messages that will encourage them to buy their products through storytelling (Hermansson \& $\mathrm{Na}, 2008)$. 


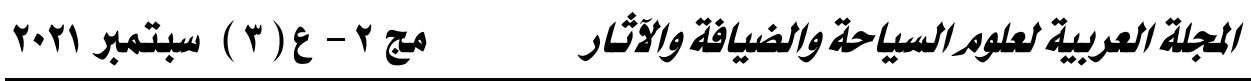

According to Simmons (2006), people desire "confidence" in the narrative you tell, which implies that story is a way to establish trust, and they want a meaningful one that inspires them to achieve the goal you promised at the beginning. As a communication technique, excellent story-telling encourages others to conceptualize the things you have told objectively based on their personal feelings, rather than pushing them to believe (Lundqvist et al., 2012). The use of brand as a competitive tactic to attract and target customers was discussed by Healey (2008). You also need to establish an image for your product or brand by telling a story that grabs attention and makes it seem desirable to a consumer.

\section{Importance of Storytelling for The Restaurant}

A restaurant's ability to emotionally connect with its consumers, emphasize its strengths, and maintain a great image is enhanced by the use of storytelling. According to Escalas \& Stern, (2003) and Mossberg \& Johansen (2006), stories capture customers' attention and convince them through narrative conveyance. In addition, stories assist consumers to grasp the benefits of a restaurant's brand, and they are less scrutinized and elicit fewer negative reactions than traditional advertising (Kaufman, 2003) A brand's uniqueness is enhanced through the use of storytelling, which produces favorable sentiments among customers (Kelley and Littman, 2006). 5 basic hints are listed below with their abbreviated names in Nguyen's (2014) storytelling marketing strategy.

\section{G.R.E.A.T}

1. Glue: Customers trust and believe in genuine things when marketing messages are used. How it targets a certain set of devoted customers who are considered the basis of the target market is what makes the narrative more effective and impactful.

2. Reward: Interesting narrative generally involves a commitment to a reward, such as losing weight, achieving financial success, or maintaining personal safety, for example. Telling them what they can 
gain, what is better for personal life, or how to attain their ambitions can get them to pay attention.

3. Emotion: Five of the hints rely on this information. In terms of psychology, a great narrative is one that evokes strong emotions and influences the customer's decision to purchase a product. Once people hear a heart-warming narrative, their hearts may begin to melt, and not simply because of the cerebral stuff.

4. Authentic: A good narrative must, first and foremost, be trustworthy. As a marketer, you do not have to ensure that the narrative is 100 percent genuine, but it should be based on the restaurant's true story. An interruption occurs instead of providing value to the brand.

5. Target: If the story is developed with the target audience in mind, then it will be successful. To guarantee that the narrative is relevant, marketers must segment their audience into groups that share similar behaviors, views, and lifestyles (Nguyen, 2014).

Yastrow (2003) showed that corporations often utilize 10 different sorts of stories: (3) success stories (4) brand value (5) brand identity and personality (6) the objective of a brand (7) brands and their consumers; (8) brands and their spokespersons; (9) brands and the society, and (10) brands' organizations, such as the restaurant's founder or management team. When restaurants communicate stories to consumers, Holt (2004) found that they may convince them not just to believe in a product, but also to buy into it. As a result, storytelling is able to establish a solid sales foundation, appeal to the requirements of target consumers, and leave a favorable impression (Comunale, 2008).

\section{Consumer Perception, Consumer Behavior and Purchase Intention Towards Storytelling}

Branding, according to Healey (2008), is a combination of stories and storytelling (Escalas \& Stern, 2003; Holt, 2004). In order to captivate customers' imaginations, branding should be done in a manner that answers their requirements and wants (Gargiulo, 2006). 


\section{- Consumer Perception}

Customers' prior assumptions and interpretations, such as their beliefs and feelings, play an important role in their perception process. Which information is perceived and the meaning of the story on a product or advertisement may vary based on consumers' prior assumptions and interpretations, such as their beliefs and feelings (Solomon et al., 2010). A range of emotive, attitudinal, and behavioral reactions are elicited by story-telling for both verbal and visual information, according to Solja (2017).

It has been proven that brand stories cause customers to be more likely to make a purchase than other kinds of marketing (Solja, 2017). Stories may have a beneficial impact on customers' purchasing decisions since consumers are more willing to accept the brand's promises without disputing them (Green \& Brock, 2000). The placement of brand stories on products can affect consumers' purchasing behavior since brand attitude has a positive relationship with purchase intention (Lundqvist et al., 2012). Other intents of customers, such as visiting a brand's website, may be favorably affected by brand stories (Gilliam and Zablah, 2013).

\section{- Consumer Behavior}

People's buying habits are studied by examining their reasons for buying products and the circumstances under which they choose to do so. Studying how customers choose and utilize products and services to meet their requirements is the goal of consumer behavior research (Andreasen \& Kotler, 2002). As a result of a wide range of age, income, education, taste, and other characteristics, consumers have quite different needs. These qualities have an impact on the behavior of the customer while making a purchase. (Solomon et al., 2010) There are a number of elements that might impact the buyer's purchasing choice. 
Cultural: As a result of socialization with family and other major institutions, a person's goals and actions are largely determined by their culture.

Social: Also, social variables such as reference groups, family, social role and status impact consumer behavior.

* Personal: Personal attributes such as gender, age, stage in life, employment, money, and lifestyle have a big impact on a buyer's selection.

Psychological: Motivation, perception, beliefs and attitudes of customers have a significant effect on the buyer selection process (Solomon et al., 2010).

\section{- Purchase Intention}

Purchase intention is the likelihood that customers will purchase a specific product. As the purchase intention increases, the likelihood of consumers purchasing the product increases. It is defined as the degree to which a consumer may suggest a product after making a purchase (Schiffman and Kanuk, 2000). Storytelling and the manner product information is presented are among the numerous elements that influence purchase intention (Shamdasani et al., 2001) They cherish the fact that stories about the goods they purchase later bring value to their lives. Alford and Btiswas (2002) highlight how today's customers tend to acquire products and services to experience stories, which reflect lifestyle.

Because customers respect the brand's style or story, or because they just like reading it, storytelling is an important tool in establishing the product's image. Consumers will also purchase this good to experience the narrative of the brand story or the brand's essence. The brand image will be used by consumers to infer or maintain their perception of the product's quality (Alford and Biswas, 2002). Customers will be more likely to buy and identify the brand if the brand image is strong enough (Faircloth et al., 2001). A good brand image will not only become a key factor in purchasing decisions but will also influence 


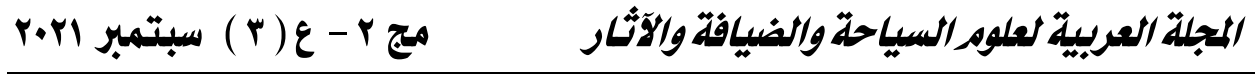

consumers' willingness to purchase a product (Kotler and Kevin, 2006).

\section{Research Methodology:}

To achieve the research aim, customers in Egyptian restaurants were surveyed. Due to the difficulty of surveying customers in all Egyptian restaurants, this study chosen Greater Cairo and Mansoura as a representative sample of the Egyptian restaurant's society. The sample equation was applied to unlimited society (Thompson, 2012) as follows:

$\mathbf{N}$ :Sample size, P: Percentage of the purpose of this study $0.50, \mathbf{d}$ : Percentage of the error limit allowed 0.05, Z:The standard degree used for giving general results is $95 \%$. Thus. the standard degree $=1.96$

$$
n=\frac{N \times p(1-p)}{\left.\left[N-1 \times\left(d^{2} \div z^{2}\right)\right]+p(1-p)\right]}
$$

$\mathrm{N}: \quad \frac{250000 \times 0.50(1-0.50)}{\left[\left(250000-1 \times\left(0.05^{2} \div 1.96^{2}\right)+0.50(1-0.50)\right]\right.}=383.58 \simeq$

The population of the study is unlimited due to the difficulty of determining a specific number of customers in Egyptian restaurants, so the random sample size is an ideal method to apply in this study. According to Thompson, (2012) the lower limit of respondents, that suitable in this study are 384. 396 electronic questionnaires were designed and distributed from $20^{\text {th }}$ October, 2020 to $25^{\text {th }}$ December, 2020. The questionnaire consisted of three sections. The first section intended to reveal the customers' demographic data. The second section intended to reveal the customers' perception of storytelling in restaurants through by object questions. The third section intended to examine the impact of storytelling on the intentions of Egyptian 
restaurant customers and examine how customers perceive storytelling at the restaurant.

The respondents were asked to answer these statements by using a five-point Likert-type scale (Strongly agree $=5$, agree $=4$, don't know $=3$, disagree $=2$ and strongly disagree $=1$ ) to determine the levels of agreement with the statements investigated. The Statistical Package for the Social Sciences (SPSS) version 25.0 was used to analyze and compute the collected data. The range of each level of agreement was calculated as follow:

Table (1): Questions Answered Scale

\begin{tabular}{|c|c|c|c|c|c|}
\hline Category & $\begin{array}{c}\text { Strongly } \\
\text { disagree }\end{array}$ & Disagree & Neutral & Agree & $\begin{array}{c}\text { Strongly } \\
\text { agree }\end{array}$ \\
\hline Code & $\mathbf{1}$ & $\mathbf{2}$ & $\mathbf{3}$ & $\mathbf{4}$ & $\mathbf{5}$ \\
\hline Range & $1-1.80$ & $\begin{array}{c}1.81- \\
2.60\end{array}$ & $\begin{array}{c}2.61- \\
3.40\end{array}$ & $\begin{array}{c}3.41- \\
4.20\end{array}$ & $4.21-5$ \\
\hline
\end{tabular}

\section{Reliability Statistics}

Table (2) : Cronbach's Alpha of Respondents' Questionnaire

\begin{tabular}{|c|c|}
\hline Cronbach's Alpha & N of statements \\
\hline .941 & 23 \\
\hline
\end{tabular}

It is evident from the data showed in Table No. (2) that the alpha coefficient of the five dimensions of the questionnaire is more than 0.70 , which is a very good indicator of the reliability of the statements of dimensions and the possibility of using these statements (Pallant, 2016), as the Alpha Cronbach coefficient for the dimensions reached .941 , which is an acceptable rate.

\section{Results and Discussion}

The results involved three main stages. Descriptive analysis was used to discover participants' responses, variance analysis for respondents' answers and regression analysis were conducted to examine the relationship between independent variables and dependent variable. The results obtained were computed and analyzed in the following tables. 
Table (3): Respondents' Demographic Data

\begin{tabular}{|c|c|c|c|}
\hline \multicolumn{2}{|r|}{ Attributes } & Frequency & $\begin{array}{c}\text { Percentage } \\
\%\end{array}$ \\
\hline \multirow{2}{*}{ Gender } & Male & 254 & 64.1 \\
\hline & Female & 142 & 35.9 \\
\hline \multicolumn{2}{|r|}{ Total } & 396 & $100 \%$ \\
\hline \multirow{4}{*}{ Age } & Less than 30 years old & 299 & 75.5 \\
\hline & $\begin{array}{c}\text { From } 30 \text { years to less than } 40 \\
\text { years }\end{array}$ & 67 & 16.9 \\
\hline & From 40 years to 50 years & 17 & 4.3 \\
\hline & More than 50 years old & 13 & 3.3 \\
\hline \multicolumn{2}{|r|}{ Total } & 396 & $100 \%$ \\
\hline \multirow{3}{*}{$\begin{array}{l}\text { Marital } \\
\text { status }\end{array}$} & Single & 272 & 68.7 \\
\hline & Married & 115 & 29.0 \\
\hline & Other & 9 & 2.3 \\
\hline \multicolumn{2}{|r|}{ Total } & 396 & $100 \%$ \\
\hline \multirow{4}{*}{$\begin{array}{l}\text { Level of } \\
\text { Education }\end{array}$} & Intermediate education & 14 & 3.5 \\
\hline & Secondary school & 3 & .8 \\
\hline & University degree & 300 & 75.8 \\
\hline & Post-graduation & 79 & 19.9 \\
\hline \multicolumn{2}{|r|}{ Total } & 396 & 100.0 \\
\hline \multirow{4}{*}{$\begin{array}{l}\text { Income / } \\
\text { month }\end{array}$} & Less than 2000 L. E & 164 & 41.4 \\
\hline & $\begin{array}{l}\text { From } 2000 \text { L.E up to less than } \\
\text { 4000 L. E }\end{array}$ & 142 & 35.9 \\
\hline & $\begin{array}{c}\text { From } 4000 \text { L.E up to less than } \\
6000 \text { L. E }\end{array}$ & 56 & 14.1 \\
\hline & More than 6000 pounds & 34 & 8.6 \\
\hline \multicolumn{2}{|r|}{ Total } & 396 & 100.0 \\
\hline
\end{tabular}

From the statistical data shown in Table (3), it is clear that more than half of the respondents are male, with a percentage of $64.1 \%$. While the percentage of females was $\underline{35.9 \%}$. 
By observing the age group of the respondents, it becomes clear to us that more than two-thirds of the respondents, with a percentage of $75.5 \%$, are of the age group of less than 30 years, while $16.9 \%$ of the age group between 30 years and less than 40 years, as for the age groups (from 40 years to 50) and (more than 50 years), their percentages were $(4.3 \%)$ and $(3.3 \%)$, respectively.

Concerning the marital status of the respondents, it became clear that there were more than half, with $(68.7 \%)$, were single, while married persons represented with (29\%). The lowest group (2.3\%) was between widows and divorced.

Agree with Solomon et al., (2010), said there are various factors that influence the way people behave in a particular situation. Consumers vary tremendously in age, income, education, tastes, and other factors. The behaviors of consumer while engaging in a purchase decision is influenced by these characteristics Consumer characteristics include four major factors and these factors are majorly responsible for the different types of behaviors depicted by the consumers. Though it does not mean that people of same, age or gender or social background are similar, because there is a lot of influence of the psychological factors that vary from individual to individual. Following factors can influence the Buying decision of the buyer.

From the data shown in the table above, it was clear that the most of the respondents are those with a university education level, at a rate of $(75.8 \%)$, and then in the order of those post graduates level by $(19.9 \%)$, while the groups of intermediate and secondary education was represented by $(3.5 \%)$ and $(0.8 \%)$, respectively.

Concerning the monthly income, it could be founded that about (41.4\%) of the total number of respondents have a monthly income of less than 2000 L.E, and this may be due to the belonging of most university students to this category, while about (35.9\%) their monthly income ranges between 2000 and less than 4000 L.E. While the lowest percentages of respondents who belonged to the category (from 4000 
pounds to less than 6000 L.E), as well as the category of (more than 6000 L.E), with percentages of (14.1\%) and (8.6\%), respectively.

Agree with Solomon et al., (2010), said that types of behaviors depicted by the consumers. However, it does not mean that people of same, age or gender or social background are similar, because there is a lot of influence of the psychological factors that vary from individual to individual.

Table (4): The Number of Times You Eat Out

\begin{tabular}{|c|c|c|}
\hline Attribute & Frequency & Percentage $\%$ \\
\hline Daily & 28 & 7.1 \\
\hline once a week & 296 & 74.7 \\
\hline More than once a week & 72 & 18.2 \\
\hline Total & $\mathbf{3 9 6}$ & $\mathbf{1 0 0 . 0}$ \\
\hline
\end{tabular}

Data in Table (4), revealed that the majority of respondent $(74.7 \%)$ ate in restaurants once a week. meanwhile respondents who ate more than once a week $18.2 \%$ only $7.1 \%$ of the investigated respondent ate in restaurants daily.

Table (5): Willing to Visit a Restaurant Just Because Hearing a Story about the Restaurant

\begin{tabular}{|c|c|c|}
\hline Attribute & Frequency & Percentage \% \\
\hline Yes & 343 & 86.6 \\
\hline No & 53 & 13.4 \\
\hline Total & $\mathbf{3 9 6}$ & $\mathbf{1 0 0 . 0}$ \\
\hline
\end{tabular}

Data in Table (5) revealed that the majority of respondent $(86.6 \%)$ visited a restaurant just because of hearing a story about the restaurant. meanwhile $13.4 \%$ answered no.

Agree with Mossberg and Johansen, (2006), said that stories catch consumers' interest and convince by what is called narrative transportation - after being immersed in a story the reader is left changed (Escalas \& Stern, 2003). Stories also help consumers understand the benefits of the brand (Kaufman, 2003), are less 
critically analyzed, and provoke fewer negative thoughts than regular advertisements (Escalas \& Stern, 2003).

Table (6): Visiting a Restaurant That Uses the Storytelling Perspective as a Marketing Tool Before

\begin{tabular}{|c|c|c|}
\hline Attribute & Frequency & Percentage \% \\
\hline Yes & 141 & 35.6 \\
\hline No & 255 & 64.4 \\
\hline Total & $\mathbf{3 9 6}$ & $\mathbf{1 0 0 . 0}$ \\
\hline
\end{tabular}

From the tabulated data, it could be noticed that the majority of respondents (64.4\%) answered no. Meanwhile, 35.6\% answered yes. That result disagreed with Nguyen (2014), who said that the storytelling marketing campaigns succeeds in the market or not, how it delivers the messages to audiences depends on 5 basic clues, which are mentioned below with a short name: G.R.E.A.T

Table (7): Telling a Story about a Restaurant Based on a Previous Experience of Visiting It

\begin{tabular}{|c|c|c|}
\hline Attribute & Frequency & Percentage \% \\
\hline Yes & 260 & 65.7 \\
\hline No & 136 & 34.3 \\
\hline Total & $\mathbf{3 9 6}$ & $\mathbf{1 0 0 . 0}$ \\
\hline
\end{tabular}

From the tabulated data, it could be noticed that the majority of respondents $(65.7 \%)$ answered yes. Meanwhile, $34.3 \%$ answered no. that agreed with Solja (2017), consumer's process information in the form of story, both verbally and visually, through narrative processing and transportation. The response process has followed by a variety of affective, attitudinal and behavioral responses.

Table (8): Type of Attraction That the Restaurant use as A Storytelling Marketing Tool

\begin{tabular}{|c|c|c|c|c|}
\hline Variable & & Frequency & $\begin{array}{c}\text { Percentage } \\
\text { \% }\end{array}$ & Rank \\
\hline $\begin{array}{c}\text { One of the Employees of } \\
\text { the Restaurant }\end{array}$ & No & 312 & 78.8 & \multirow{2}{*}{6} \\
\cline { 2 - 4 } & Yes & 84 & 21.2 & \\
\hline
\end{tabular}




\begin{tabular}{|c|c|c|c|c|}
\hline \multicolumn{2}{|l|}{ Total } & 396 & 100.0 & \\
\hline \multirow{2}{*}{$\begin{array}{c}\text { One of Colleagues or } \\
\text { Friends }\end{array}$} & No & 230 & 58.1 & \multirow{3}{*}{3} \\
\hline & Yes & 166 & 41.9 & \\
\hline \multicolumn{2}{|l|}{$\begin{array}{c}\text { Total } \\
\end{array}$} & 396 & 100.0 & \\
\hline \multirow{2}{*}{ Television } & No & 345 & 87.1 & \multirow{3}{*}{7} \\
\hline & Yes & 51 & 12.9 & \\
\hline \multicolumn{2}{|l|}{ Total } & 396 & 100.0 & \\
\hline \multirow{2}{*}{ Social Media } & No & 118 & 29.8 & \multirow{3}{*}{1} \\
\hline & Yes & 278 & 70.2 & \\
\hline \multicolumn{2}{|l|}{ Total } & 396 & $\mathbf{1 0 0 . 0}$ & \\
\hline \multirow{2}{*}{ Promoting \& Advertising } & No & 227 & 57.3 & \multirow{3}{*}{2} \\
\hline & Yes & 169 & 42.7 & \\
\hline \multicolumn{2}{|l|}{ Total } & 396 & 100.0 & \\
\hline \multirow{2}{*}{ Mobil Messages } & No & 351 & 88.6 & \multirow{3}{*}{8} \\
\hline & Yes & 45 & 11.4 & \\
\hline \multicolumn{2}{|l|}{ Total } & 396 & $\mathbf{1 0 0 . 0}$ & \\
\hline \multirow{2}{*}{$\begin{array}{l}\text { Applications for Ordering } \\
\text { Food }\end{array}$} & No & 262 & 66.2 & \multirow{3}{*}{4} \\
\hline & Yes & 134 & 33.8 & \\
\hline \multicolumn{2}{|l|}{$\begin{array}{c}\text { Total } \\
\end{array}$} & 396 & 100.0 & \\
\hline \multirow{2}{*}{$\begin{array}{c}\text { A Video of a Restaurant } \\
\text { Critic }\end{array}$} & No & 300 & 75.8 & \multirow{3}{*}{5} \\
\hline & Yes & 96 & 24.2 & \\
\hline Total & & 396 & $\mathbf{1 0 0 . 0}$ & \\
\hline
\end{tabular}

From the previous table, it was clear that there are many sources for obtaining information about the restaurant and attracting attention towards it. We could find that social media websites have the highest percentage $(70.2 \%)$ from the customers' point of view, while in the second and third places were the advertising for the restaurant, as well as colleagues and friends, at percentages (42.7\%) and (41.9\%) respectively.

Agree with Simmons (2006), said that with the development of information technology, the roles of storytelling in daily life have 
changed remarkably. The growth of social network has helped to form the online communities, the "urban tribes" as new means.

Also Agree with All (2013), says every brand has a story and, "Great stories are more valuable to a brand than ever before, and storytelling is an organization's greatest secret weapon in its quest to differentiate itself from its competition".

The food ordering applications came in the fourth place, with a percentage of (33.8\%), this result disagreed with Simmons (2006), who said that new challenges for marketers to progress with the restaurants. It is no longer a one-way exchange, but now bloggers or members can respond or give feedbacks to make storytelling an increasingly widespread tool of two-way communication between one particular or general brand and its target customer groups.

Respondents believed that one of the most influential factors was the availability of a video for a food critic and that they heard a story about the restaurant from one of its employees, with percentages of $(24.2 \%)$ and $(21.2 \%)$

Finally, respondents saw that one of the less important marketing attractions for restaurants is their dependence on television by a percentage (12.9\%) and mobile messages by (11.4\%).this result disagreed with Nguyen (2014), who stated that it is the connection of marketing messages to what the consumers trust and believe in real what makes the storytelling way more efficient and powerful is about how it aims to a particular loyal group that considered themselves as foundation in target market.

Table (9): Factors of Making the Decision to go to Restaurants

\begin{tabular}{|c|c|c|c|c|}
\hline Variable & & Frequency & $\begin{array}{c}\text { Percentage } \\
\text { \% }\end{array}$ & Rank \\
\hline \multirow{2}{*}{$\begin{array}{c}\text { The reputation of the } \\
\text { restaurant }\end{array}$} & No & 117 & 29.5 & \multirow{3}{*}{3} \\
\cline { 2 - 4 } Total & Yes & 279 & 70.5 & \\
\hline \multicolumn{2}{|c|}{} & $\mathbf{3 9 6}$ & $\mathbf{1 0 0 . 0}$ & \\
\hline \multirow{2}{*}{ Restaurant success stories } & No & 112 & 28.3 & \multirow{2}{*}{2} \\
\cline { 2 - 4 } & Yes & 284 & 71.7 & \\
\hline
\end{tabular}




\begin{tabular}{|c|c|c|c|c|}
\hline \multicolumn{2}{|l|}{ Total } & 396 & 100.0 & \\
\hline \multirow{2}{*}{ Restaurant prices } & No & 174 & 43.9 & \multirow{3}{*}{5} \\
\hline & Yes & 222 & 56.1 & \\
\hline \multicolumn{2}{|l|}{ Total } & 396 & 100.0 & \\
\hline \multirow{2}{*}{$\begin{array}{c}\text { Cleanliness and general } \\
\text { atmosphere of the } \\
\text { restaurant }\end{array}$} & No & 111 & 28.0 & \multirow{3}{*}{1} \\
\hline & Yes & 285 & 72.0 & \\
\hline \multicolumn{2}{|l|}{$\begin{array}{c}\text { Total } \\
\end{array}$} & 396 & 100.0 & \\
\hline \multirow{2}{*}{ social position } & No & 344 & 86.9 & \multirow{3}{*}{8} \\
\hline & Yes & 52 & 13.1 & \\
\hline \multicolumn{2}{|l|}{ Total } & 396 & 100.0 & \\
\hline \multirow{2}{*}{$\begin{array}{l}\text { Professional dealing for } \\
\text { workers }\end{array}$} & No & 270 & 68.2 & \multirow{3}{*}{6} \\
\hline & Yes & 126 & 31.8 & \\
\hline \multicolumn{2}{|l|}{$\begin{array}{c}\text { Total } \\
\end{array}$} & 396 & 100.0 & \\
\hline \multirow{2}{*}{ Food safety and quality } & No & 128 & 32.3 & \multirow{3}{*}{4} \\
\hline & Yes & 268 & 67.7 & \\
\hline \multicolumn{2}{|l|}{ Total } & 396 & 100.0 & \\
\hline \multirow{2}{*}{$\begin{array}{l}\text { Nominate one of the } \\
\text { individuals }\end{array}$} & No & 273 & 68.9 & \multirow{3}{*}{7} \\
\hline & Yes & 123 & 31.1 & \\
\hline Total & & 396 & 100.0 & \\
\hline
\end{tabular}

From the data in the previous table it was found that there are some factors that help to make the decision to visit the restaurant, it became clear from the respondents' point of view that the most influencing factors on the decision of visiting the restaurant were (cleanliness and the general atmosphere of the restaurant, the success stories of the restaurant, as well as the reputation of the restaurant, where it came in percentages $(72 \%),(71.7 \%),(70.5 \%)$ respectively, These results agreed with Kelley and Littman, (2006) who said that storytelling generates positive feelings in customers and is perceived as more convincing than facts, increasing brand trust, raising awareness and making the brand unique. 
In terms of impact, food safety and quality came in the order of food menus prices, with percentages of (67.7\%) and (56.1\%)

Respondents believed that the professional interaction of the restaurant's workers, as well as the nomination of a person to visit the restaurant, are among the factors that could affect the decision to visit the restaurant, as it came in close percentages $(31.8 \%, 31.8 \%)$.

Finally, it could be noticed that the social position affects by the lowest percentage $(13.1 \%)$ on making a restaurant visit decision, that result disagreed with Solomon et al., (2010) who said that it does not mean that people of same, age or gender or social background are similar, because there is a lot of influence of the psychological factors that vary from individual to individual.

Table (10): Descriptive Statistics

The Impact of Storytelling on the Intentions of Egyptian Restaurant Customers

\begin{tabular}{|c|c|c|c|c|}
\hline Variable & $\underset{\mathbf{n}}{\mathrm{Mea}}$ & \begin{tabular}{|c|} 
Std. \\
Deviatio \\
$\mathrm{n}$
\end{tabular} & $\begin{array}{c}\text { Varian } \\
\text { ce }\end{array}$ & Rank \\
\hline \multicolumn{5}{|c|}{ Standard Specification for The Story } \\
\hline $\begin{array}{l}\text { 1- Story Standard [use of story style] } \\
\text { establishes the restaurants' reputation among } \\
\text { the competitors }\end{array}$ & 3.53 & .950 & .903 & 7 \\
\hline $\begin{array}{l}\text { 2- Realistic story is one of the most } \\
\text { important standard features of the story }\end{array}$ & 3.67 & 1.122 & 1.258 & 1 \\
\hline $\begin{array}{l}\text { 3- The story is a way to build trust with } \\
\text { guests }\end{array}$ & 3.42 & 1.017 & 1.034 & 11 \\
\hline $\begin{array}{l}\text { 4- The story is characterized by clear } \\
\text { vision }\end{array}$ & 3.62 & .894 & .799 & 4 \\
\hline $\begin{array}{l}\text { 5- The story is considered an effective } \\
\text { marketing tool that restaurants have used in } \\
\text { recent times }\end{array}$ & 3.49 & 1.052 & 1.106 & 8 \\
\hline $\begin{array}{l}\text { 6- The story is summarized in one or two } \\
\text { sentences }\end{array}$ & 3.19 & 1.000 & .999 & 20 \\
\hline
\end{tabular}


7- The story aims to convey one specific message about the restaurant

\begin{tabular}{|l|l|l|l|}
3.33 & 1.047 & 1.096 & 15 \\
\hline
\end{tabular}

\section{The effect of storytelling on customers' buying intentions}

8- The effect of storytelling on customers' purchase intentions [The story-telling style

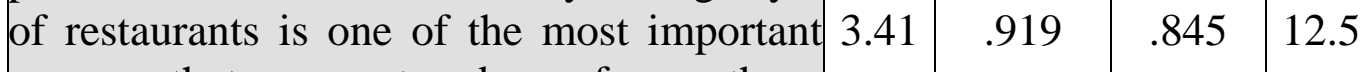
means that pay to buy from those restaurants]

9- Willingness to pay more money in restaurants that have interesting stories as advertisements

$10-$ We always tell the stories that I hear about restaurants

11- The storytelling of restaurants always gives a picture of the quality of products and 3.01

1.073

1.152

22 services

12- Restaurants' use of storytelling style increases my interest in purchasing their 3.32

3.23
3.48

1.005

1.009

19 products

13- Storytelling style helps in making better decisions before purchasing products from restaurants.

14- Recommending to deal with restaurants that provide narration of their brand's

3.48

1.002

1.005

9.5 success stories

15- Definitely trying to deal with restaurants that do marketing by storytelling

16- Food and service in the restaurant is one of the things I enjoy in storytelling

\begin{tabular}{|c|c|c|c|}
\hline 3.35 & .988 & .977 & 14 \\
\hline 3.60 & 1.016 & 1.031 & 5.5 \\
\hline 3.66 & 1.025 & 1.051 & 2 \\
\hline
\end{tabular}

Storytelling obstacles and challenges

17- When hearing the storytelling of a restaurant, it increases my curiosity to visit it

3.65

1.022

1.044

3

\begin{tabular}{l|l|l}
1.016 & 1.033 & 16
\end{tabular}

.971

.944

9.5

3.35 $\overline{T \wedge T}$ 
The Impact of Storytellin ..

\begin{tabular}{|c|c|c|c|c|}
\hline $\begin{array}{l}\text { 18- Storytelling Obstacles and Challenges } \\
\text { The marketing tool used is one of the } \\
\text { limitations and challenges of storytelling }\end{array}$ & 3.12 & 1.019 & 1.038 & 21 \\
\hline $\begin{array}{l}\text { - One of the obstacles and challenges of } \\
\text { orytelling is how to communicate the story }\end{array}$ & 3.27 & 1.117 & 1.249 & 18 \\
\hline $\begin{array}{l}20 \text { - In your opinion, suspense and } \\
\text { excitement are among the obstacles and } \\
\text { challenges of storytelling }\end{array}$ & 2.93 & 1.140 & 1.299 & 23 \\
\hline $\begin{array}{l}\text { - From your point of view, the method of } \\
\text { orkers is one of the obstacles and } \\
\text { allenges of storytelling }\end{array}$ & 3.29 & 1.023 & 1.046 & 17 \\
\hline $\begin{array}{l}\text { - Prolongation and boredom are obstacles } \\
\text { d challenges of storytelling }\end{array}$ & 3.60 & 1.059 & 1.122 & 5.5 \\
\hline $\begin{array}{l}\text { - One of the limitations and challenges of } \\
\text { rytelling is the price of meals in the } \\
\text { staurant }\end{array}$ & & 1.038 & 1.078 & 12.5 \\
\hline
\end{tabular}

As presented at table (10) it could be noticed that the average of Standard specification for the story attributes ranged between 3.19 to 3.67 which mean that respondents' perceptions towards Standard specification for the story ranged between neutral and agree.

They were neutral that:

1- The story is summarized in one or two sentences (3.19)

2- The story aims to convey one specific message about the restaurant (3.33)

Sentences number two and three agree with Fog et al, (2010) Stories always make a point that is valued (positively or negatively) by the audience. Each story should convey only one single message, which has clearly focused so that it can be summarized in only one or two sentences (Twitchell, 2004).

They were agreeing that:

1- Story Standard [use of story style] establishes the restaurants' reputation among the competitors (3.53)

2- Realistic story is one of the most important standard features of 


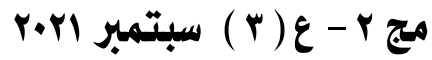 \\ المجلة العربية لعلوم السياحة والضيافة والآثار}

the story (3.67)

3- The story is a way to build trust with guests (3.42)

4- The story is characterized by clear vision (3.62)

5- The story is considered an effective marketing tool that restaurants have used in recent times (3.49)

As presented at table it could be noticed that the average of the effect of storytelling on customers' buying intentions attributes ranged between 3.01 to 3.66 which means that respondents' perceptions towards the effect of storytelling on customers' buying intentions ranged between neutral and agree.

They were neutral that:

1- Willingness to pay more money in restaurants that have interesting stories as advertisements

2- We always tell the stories that I hear about restaurants (3.23)

3- Restaurants' use of storytelling style increases my interest in purchasing their products (3.32)

4- Definitely trying to deal with restaurants that do marketing by storytelling (3.35)

They were agreeing that:

1- The effect of storytelling on customers' purchase intentions [The story-telling style of restaurants is one of the most important means that pay to buy from those restaurants

2- The storytelling of restaurants always gives a picture of the quality of products and service (3.48)

3- Storytelling style helps in making better decisions before purchasing products from restaurants. (3.65)

4- Recommending to deal with restaurants that provide narration of their brand's success stories (3.48)

5- Food and service in the restaurant is one of the things I enjoy in storytelling (3.60)

6- When hearing the storytelling of a restaurant, it increases my curiosity to visit it (3.66) 
As presented at table it could be noticed that the average of Storytelling obstacles and challenges attributes ranged between 2.93 to 3.60 which means that respondents' perceptions towards Storytelling obstacles and challenges ranged between neutral and agree.

Sentences number one and three agree with Schiffman and Kanuk, (2000) Purchase intention is the likelihood that customers will purchase a specific product. As the purchase intention increases, the likelihood of consumers purchasing the product increases. It is defined as the degree to which a consumer may suggest a product after making a purchase.

They were neutral that:

1) Storytelling Obstacles and Challenges The marketing tool used is one of the limitations and challenges of storytelling (3.12)

2) One of the obstacles and challenges of storytelling is how to communicate the story (3.27)

3 ) In your opinion, suspense and excitement are among the obstacles and challenges of storytelling (2.93)

4) From your point of view, the method of workers is one of the obstacles and challenges of storytelling (3.29)

Sentences number one agrees with Solja, (2017), said that restaurant marketing is no longer a one-way exchange due to the development of information technology and the growth of new marketing challenges. Instead, bloggers or members can now respond or give feedbacks, making storytelling a more widely used tool for two-way communication between a brand and its target customer groups.

They were agreeing that:

1- Prolongation and boredom are obstacles and challenges of storytelling (3.60)

2- One of the limitations and challenges of storytelling is the price of meals in the restaurant (3.41) 


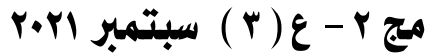

\section{المجلة العربية لعلور السياحة والضيافة والوآثار}

\section{Testing Hypotheses}

Table (11) : Impact of Storytelling on the Intentions of Egyptian Restaurant Customers According to their Demographical Data"H.1"

\begin{tabular}{|c|c|c|c|c|c|}
\hline $\begin{array}{c}\text { Spearman's } \\
\text { Correlation }\end{array}$ & $\begin{array}{c}\text { Gender } \\
\text { H 1.1 }\end{array}$ & $\begin{array}{c}\text { Age } \\
\text { H 1.2 }\end{array}$ & $\begin{array}{c}\text { Marria } \\
\text { ge } \\
\text { Status } \\
\text { H 1.3 }\end{array}$ & $\begin{array}{c}\text { Educati } \\
\text { onal } \\
\text { Level } \\
\text { H 1.4 }\end{array}$ & $\begin{array}{c}\text { Monthl } \\
\text { Income } \\
\text { H 1.5 }\end{array}$ \\
\hline $\begin{array}{c}\text { Correlation } \\
\text { Coefficient }\end{array}$ & .035 & $-.299-^{* *}$ & $-.342--^{* *}$ & .084 & $-.274--^{* *}$ \\
\hline Sig. (2-tailed) & .482 & .000 & .000 & .096 & .000 \\
\hline N & 396 & 396 & 396 & 396 & 396 \\
\hline
\end{tabular}

** Correlation is significant at the 0.05 level (2-tailed).

\section{H. Hypothesis}

With regard to Table (11), the results of Spearman's correlation showed that there are significant differences on 0.05 degree between the impact of storytelling on the intentions of Egyptian restaurant customers returns to their "Age H1.2", which correlation coefficient (-.299-), and Sig. (.000) "less than 0.05". Also, there are significant differences on 0.05 degree between the impact of storytelling on the intentions of Egyptian restaurant customers back to their "Marriage status H1.3", which correlation coefficient (-.342-), and Sig. (.000) "less than 0.05". Moreover furthermore, there are significant differences on 0.05 degree between the impact of storytelling on the intentions of Egyptian restaurant customers back to their "Monthly income H1.5", which correlation coefficient (-.274-), and Sig. (.000) "less than 0.05".

The results of Spearman's correlation of demographical data showed that there are no significant differences on 0.05 degree between the impact of storytelling on the intentions of Egyptian restaurant customers back to their "Gender H1.1", which correlation coefficient (.035), and Sig. (.482) "more than 0.05". In addition to that there are no significant differences on 0.05 degree between the impact of 
storytelling on the intentions of Egyptian restaurant customers back to their "Educational level H1.4", which correlation coefficient (.084), and Sig. (.096) "more than 0.05".

Table (12) : Impact of storytelling on the intentions of Egyptian restaurant customers according to their object data" H.2"

\begin{tabular}{|c|c|c|c|c|c|c|}
\hline $\begin{array}{c}\text { Spear } \\
\text { man's } \\
\text { Correl } \\
\text { ation }\end{array}$ & $\begin{array}{c}\text { Times } \\
\text { Eating } \\
\text { Out } \\
\text { H } \mathbf{2 . 1}\end{array}$ & $\begin{array}{c}\text { Visiting } \\
\quad \text { a } \\
\text { Restaura } \\
\text { nt Using } \\
\text { Storytelli } \\
\text { ng as a } \\
\text { Marketin } \\
\text { g Tool } \\
\text { H } 2.2\end{array}$ & $\begin{array}{c}\text { Telling a } \\
\text { Story } \\
\text { about a } \\
\text { Restaurant } \\
\text { Based On } \\
\text { a Previous } \\
\text { Experienc } \\
\text { e } \\
\text { H } 2.3\end{array}$ & $\begin{array}{c}\text { Visiting } \\
\text { a } \\
\text { Restaur } \\
\text { ant } \\
\text { upon } \\
\text { Hearing } \\
\text { His } \\
\text { Story } \\
\text { H 2.4 }\end{array}$ & $\begin{array}{c}\text { Attractions } \\
\text { that } \\
\text { Restaurant } \\
\text { Using } \\
\text { Storytelling } \\
\text { as a } \\
\text { Marketing } \\
\text { Tool } \\
\text { H 2.5 }\end{array}$ & $\begin{array}{c}\text { Factors } \\
\text { That } \\
\text { Making } \\
\text { the } \\
\text { Decision } \\
\text { to Go To } \\
\text { Restaurant } \\
\text { s } \\
\text { H } 2.6\end{array}$ \\
\hline $\begin{array}{l}\text { Correl } \\
\text { ation } \\
\text { Coeffic } \\
\text { ient }\end{array}$ & $.165^{* *}$ & $-.030-$ & $-.062-$ & $-.251-^{* *}$ & $.219^{* *}$ & $.145^{* *}$ \\
\hline $\begin{array}{c}\text { Sig. } \\
(2- \\
\text { tailed })\end{array}$ & .001 & .550 & .215 & .000 & .000 & .004 \\
\hline $\mathbf{N}$ & 396 & 396 & 396 & 396 & 396 & 396 \\
\hline
\end{tabular}

**. Correlation is significant at the 0.05 level (2-tailed).

H. Hypothesis

As it can be observed from table (12), the results of Spearman's correlation showed that there are significant differences on 0.05 degree between the impact of storytelling on "Times eating out H2.1", which correlation coefficient (.165), and Sig. (.001) "less than $0.05 "$. Also, there are significant differences on 0.05 degree between the impact of storytelling on "Visiting a restaurant upon hearing his story H2.4", which correlation coefficient (-.251-), and Sig. (.000) "less than 0.05". Moreover, there are significant differences on 0.05 degree between the impact of storytelling on "Attractions that restaurant using storytelling as a marketing tool $\mathrm{H} 2.5$ ", which 
correlation coefficient (.219), and Sig. (.000) "less than 0.05". Furthermore, there are significant differences on 0.05 degree between the impact of storytelling on "Factors that making the decision to go to restaurants $\mathrm{H} 2.6$ ", which correlation coefficient (.145), and Sig. (.004) "less than 0.05".

Finally, the results of Spearman's correlation of object data showed that there are no significant differences on 0.05 degree between the impact of storytelling on "Visiting a restaurant using storytelling as a marketing tool H2.2", which correlation coefficient (-.030-), and Sig. (.550) "more than $0.05 "$ ". In addition to that there are no significant differences on 0.05 degree between the impact of storytelling on "Telling a story about a restaurant based on a previous experience H2.3", which correlation coefficient (-.062-), and Sig. (.215) "more than $0.05 "$.

\section{Conclusion}

This paper has presented an investigation into determining the impact of storytelling on the intentions of Egyptian restaurant customers. Customers have sufficient awareness of restaurant storytelling. With regard to analyze customers' intentions towards storytelling, the majority of customers are aware of storytelling concept and intend to go to a restaurant that uses this perspective, which the average of respondents' answers was agree in some statements.

Summarize the research results; there is a significant variance between the impact of storytelling on the intentions of Egyptian restaurant customers returns to their (age, marriage status, and monthly income). On the other hand, the results of correlation of demographical data showed that there are no significant differences between the impact of storytelling on the intentions of Egyptian restaurant customers back to their (gender, and educational level).

As it can be observed from the object data results correlation showed that there are significant differences between the impact of storytelling on (Times eating out, Visiting a restaurant upon hearing his story, 
Attractions that restaurant using storytelling as a marketing tool, Factors that making the decision to go to restaurants). From other side, there are no significant differences between the impacts of storytelling on (Visiting a restaurant using storytelling as a marketing tool, telling a story about a restaurant based on a previous experience) .

Finally, this research paper confirms that restaurants that use the perspective of storytelling as a marketing method attract a large number of customers and thus affect their purchasing intentions towards the restaurant.

\section{Recommendations}

1. The restaurants should use the concept of storytelling as one of the new marketing tools to attract a new segment of customers.

2. Train employees in restaurants on how to use the marketing storytelling perspective.

3. Restaurants use mobile messages or a mobile application as one of the storytelling methods for easier and faster access to customers.

4. The restaurant management cooperated with a restaurant critic and used his channel or personal page on social media as a means of storytelling.

5. Restaurant management should be hired in officials or marketing personnel who have sufficient experience with the concept of storytelling. 


\section{References}

1. Alford, B.L.; Biswas, A. (2002). The elects of discount level, price consciousness and sale proneness on consumers' price perception and behavioral intention. J. Bus. Res., 55, 775-783.

2. All, D. (2013), "Reach millennials through storytelling for good", available at: www.huffingtonpost.com/david-all/reach-millennialsthrough_b_3639040.html (accessed 9 December 2013).

3. Andreasen AR, Kotler P. (2002). Strategic Marketingfor NonProfit Organizations (6th edn). PrenticeHall: Upper Saddle River NJ.

4. Austad, K. (2019). Aligning Employee Behavior with an Organization's Core Values through Inquiry and Storytelling (Doctoral dissertation, The College of St. Scholastica).

5. Brown, J. S., Denning, S., Groh, K., \& Prusak, L. (2005). Storytelling in organizations: Why storytelling is transforming 21st century organizations and management. Routledge.

6. Comunale, A. (2008). You are what you wear: A conceptual study of the fashion branding practices of $H \& M$, Forever 21, and Urban Outfitters. Retrieved on October 21, 2010 from: http://www.library.drexel.edu/publications/dsmr/Communale.pdf

7. Escalas, J. E., \& Stern, B. B. (2003). Sympathy and empathy: Emotional responses to advertising dramas. Journal of Consumer Research, 29, 566-578.

8. Faircloth, J.B.; Cappella, L.M.; Alford, B.L. (2001). The Effect of Brand Attitude and Brand Image on Brand Equity. J. Mark. Theory Pract., 9, 61-75.

9. Fog, K., Budtz, C., Munch, P. and Blanchette, S. (2010), Storytelling: Branding in Practice, 2nd ed., Springer, Berlin.

10. Gargiulo, L T. (2006). Power of stories. The Journal for Quality \& Participation, Spring, 1-8. 
11. Gilliam, D. A. \& Zablah, A. R., (2013). Storytelling during retail sales encounters. Journal of Retailing and Consumer Services, 20(5), pp. 488-494.

12. Green, M. C. \& Brock, T. C., (2000). The role of transportation in the persuasiveness of public narratives. Journal of Personality and Social Psychology, 79(5), pp. 701-721

13. Hamm, J. (2013), "Why agencies and brands need to embrace true storytelling", available at: www.adweek.com/news/advertisingbranding/why-agencies-and-brands-need-embracetrue- storytelling152534 (accessed 17 December 2020).

14. Healey, M. (2008). What is branding? RotoVision, SA, Hove, UK.

15. He, Y. (2011). Brand storytelling: A comparison of the brand stories of Tiffany and Bulgari. University of Nebraska at Omaha.

16. Hermansson, E., \& Na, J. (2008). How Does a Company Communicate through Storytelling?-a study of the storytelling techniques used in two companies. bachelor thesis, Kristianstad University, Sweden.

17. Holt, D. B. (2004). How brands become icons. Cambridge, MA: Harvard University

18. Kaufman, B. (2003). Stories that sell, stories that tell. Journal of Business Strategy, 24 (2), 11-15.

19. Kelley, T. and Littman, J. (2006). The ten faces of innovation: Strategies for heightening creativity. London, Profile Books.

20. Kotler, P.; Kevin, L.K. (2006). Marketing Management, 12th ed.; Prentice-Hall, Inc.: Upper Saddle River, NJ, USA.

21. Lundqvist, A., Lijander, V., Gummerus, J. \& Riel, A. v., (2012). The impact of storytelling on consumer brand experience: The case of a firm-originated story. Journal of Brand Management, 20(4).

22. Mossberg, L. and Johansen, E. (2006). Storytelling: Marknadsföring $i$ upplevelseindustrin (storytelling: Marketing in the experience industry), Göteborg, Studentlitteratur. 
23. Nguyen, V.(JBI). (2014). Storytelling Marketing - Marketing bằng cách kể chuyện. Article from jbi.nguyenvu.me. Accessed 15 February 2020. http://jbi.nguyenvu.me/storytellingmarketingmarketing-bang-cach-ke-chuyen/

24. Pallant, J. (2016). SPSS survival manual, 6th Ed., Berkshire, McGraw-Hill Education (UK).

25. Park, A. R., \& Cho, M. S. (2010). The effect of storytelling on purchase behavior in local food restaurant. Journal of the Korean Society of Food Culture, 25(6), 764-769.

26. Schiffman, L.G.; Kanuk, L.L. (2000). Consumer Behavior, 7th ed.; Prentice Hall: New York, NY, USA.

27. Shamdasani, P.N.; Stanaland, A.J.; Tan, J. (2001). Location, location, location: Insights for advertising placement on the web. J. Advert. Res., 41, 7-21.

28. Shankar, A., Elliot, R. and Goulding, C. (2001). Understanding consumption: Contributions from a narrative perspective. Journal of Marketing Management, 17 (3/4), 429-453.

29. Simmons, J. (2006). Guinnes and the role of strategic storytelling. Journal of Strategic Marketing, 14 (March), 11-18.

30. Solja, E., (2017). Let me tell you a story: Consumer responses to company-created brand stories, s.l.: Doctoral Thesis.

31. Solomon M., Bamossy G., Askegaard S., and Hogg, M.K. (2010). Consumer Behaviour. A European Perspective. Harlow: Pearson Education.

32. Thompson, S. K., (2012) "Sampling", Third Edition, John Wiley \& Sons, Inc, U.S. 59-60.

33. Twitchell, J. B. (2004). An English teacher looks at branding. Journal of Consumer Research, 32 (2), 484-489.

34. Van Hulst, M. (2012). Storytelling, a model of and a model for planning. Planning Theory, 11(3), 299-318. 
35. -Yastrow, S. (2003). Brand Harmony: Achieving Dynamic Results by Orchestrating Your Customer's Total Experience. New York, NY: SelectBooks. 